\title{
Early Copper Finds in Northern Fennoscandia
}

\author{
Anders Huggert
}

\begin{abstract}
A rough casting for a very early copper adze, found not long ago in the interior of Upper Norrland has been shown by analysis to be of very pure copper $-99.4 \%$. The author has used the occasion to study the early use of copper in northern Fennoscandia. The earliest evidence is from ca. 3900 B.C., and in this case there were indications that metal was actually being melted. The copper studied was all of eastern/south-eastern origin; copper began reaching Upper Norrland via south Scandinavia only much later. The author surveys some of the main features in the development of metalworking in the forest region between the Urals and Karelia and also further south. In this vast area are found the preconditions for the production of copper objects in northern Fennoscandia. The material is viewed against the background of an earlier study by the author of the import of north Russian Carboniferous flint into Upper Norrland between the Middle Neolithic and the Epineolithic.
\end{abstract}

Anders Huggert, Västerbottens museum, Box 6083, S-903 42 Umeå. Siveden.

\section{COPPER ARTIFACTS IN NORTHERN FENNOSCANDIA}

There is no evidence that local copper resources were exploited in Upper Norrland in prehistoric times. Metal was imported from somewhere else. In the early stages it was copper with its own natural chemical composition and purity, with any alterations processing might have caused. Later on alloys were introduced, which were the result of a knowledge of metallurgical processes. It has long been agreed that in the Bronze Age metal came to Upper Norrland from two main areas - Central Europe (via south Scandinavia) and NE Russia (via Finland) (Gimbutas 1965; Bakka 1976).

Metal import from southern Scandinavia was connected with the expansion of settlement along Norrland's coast, as seen not least in the imposing burial cairns. However some copper artifacts could have reached the area even earlier. The people of the Battleaxe Culture made limited use of metal, as shown by the contents of an inhumation grave in Östergötland and another in Scania (Malmer 1962). The Östergötland grave contained some small spiral beads of remarkably pure copper, in which the only trace elements reported were $<0.001 \%$ silver, $<0.001 \%$ gold, and $<0.001 \%$ nickel (Oldeberg 1976:73). The geographical range of this Middle Neolithic culture clearly also included parts of coastal and inland Norrland (e.g. Huggert 1992, 1993). We should not forget two small pieces of copper or bronze sheeting that were found in the excavation of the settlement of Jettböle II on Åland, which also dates from the end of the Middle Neolithic (Meinander 1954:197). This settlement belonged to the Swedish Pitted Ware Culture, 
and its pottery contained elements regarded as clearly related to Swedish and Finnish battleaxe ceramics (Meinander 1957; Kivikoski 1964).

As our subject is going to be metal import from the east to northern Fennoscandia, including Upper Norrland, we may begin by pointing out that until the early 1980's it was thought that metal was not imported from the east until the Seima stage, which is placed by calibrated radiocarbon dating somewhere between the $16 \mathrm{th} / 15 \mathrm{th}$ and the 14th centuries B.C. (Chernykh 1992:194). Imports increased during the Ananino stage. However recent discoveries have shown that the import of copper from the east began much earlier. Attention will here be given to five discoveries - two in eastern Finland, one in northern Norway, and two in Upper Norrland in Sweden (fig. 1).

A ring of pure copper (fig. 2:1) was found during the excavation of a settlement on the edge of a peat bog on the western slope of the Suovaara headland in Polvijärvi in northern Karelia. Together with the ring were found typical Comb Ware with asbestos tempering and thin-walled asbestos ware. The discovery was made in 1960, when it was still too early to understand the age and meaning of the copper object correctly. J.-P. Taavitsainen dated the object to the typical Comb Ware period, more precisely at ca. 3000 B.C. (1982), which would be the equivalent of ca. 3800 B.C. on a calibrated chronology.

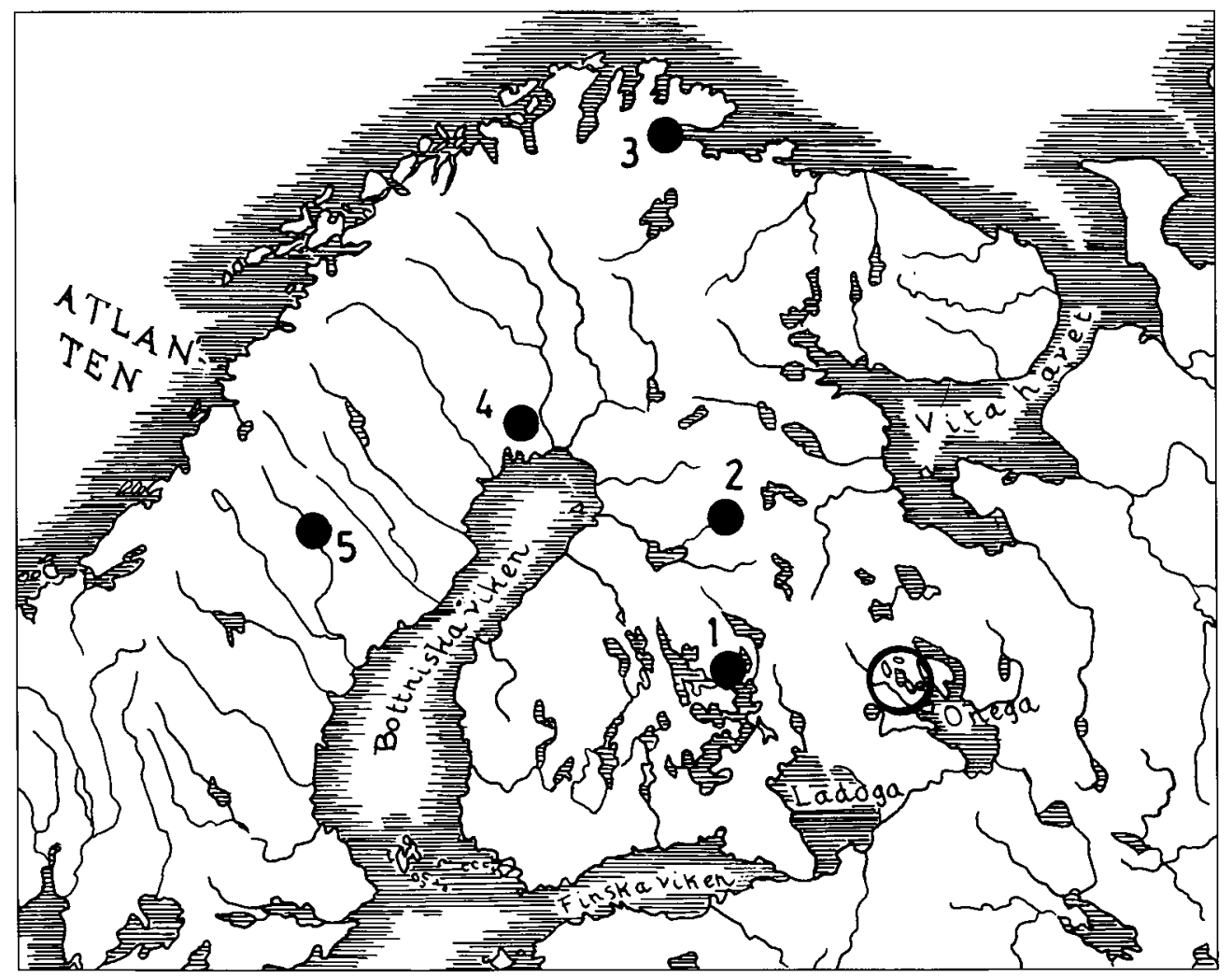

Fig. 1. Five of the sites in northern Fennoscandia where early copper object with eastern connections have been found: 1) Polvijärvi, 2) Kukkosaari, 3) Karlebotn, 4) Lillberget, 5) Varris. The copper bearing area near Lake Onega is marked with a circle. 


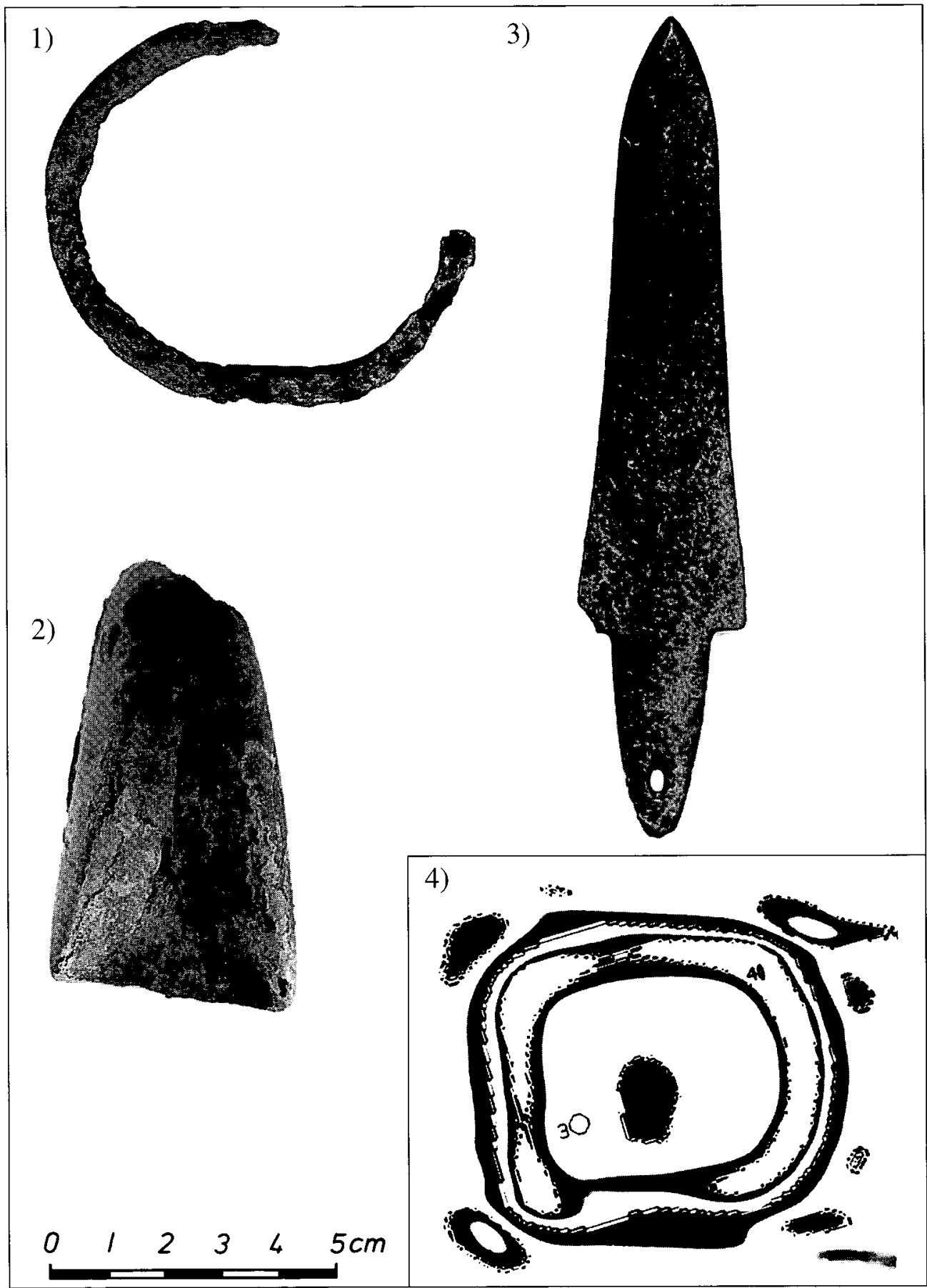

Fig. 2. Four of the copper objects: I) the ring from Polvijarvi, 2) the adze from Kukkosaari, 3) the dagger from Karlebotn, 4) the bead from Lillberget enlarged, section based on X-ray tomography. 1 and 2 photographs from Museiverket, Helsinki, 3 from Troms $\phi$ museum, and 4 after Halén (1994). considerably enlarged. 
A hollow-bladed adze of copper (fig. 2:2) was found in an occupation area on the island of Kukkosaari in Suomussalmi in Kainuu. This object was not shaped by casting, but is forged from a flat piece of metal whose sides have been folded in towards the middle. The object has a shape like a stone implement. Its dating is unsure. The other material from the site extends from preceramic times down at least to the Bronze Age. Matti Huurre places the adze in the 3rd millennium B.C. (1982, 1986), which allowing for calibration would be ca. 2500-3800 B.C. Other copper and bronze objects, and also moulds (fig. 5), are reported from sites at Suomussalmi.

The dating possibilities are considerably better in the case of a copper dagger, which was found during the excavation of a rectangular pit-house with midden in Karlebotn in Finnmark, northern Norway (fig. 2:3). The associated finds and calibrated 14C dates indicate that the settlement was in use in ca. 1900-1800 B.C. The dagger was made by forging and grinding. Its form recalls that of a number of daggers and points of slate (Schanche 1986, 1989, 1994:193f.). The Karlebotn publication also refers to a flat piece of hammered copper, which was found together with textile-marked pottery and imitation textile-marked pottery, and scrapers of quartz and quartzite at Storbukt on Magerøya (Gjessing 1935, 1942). The publication also mentions a hammered copper arrowhead among the finds from a house at Ledesby in Finnmark. The finds from the same stratum included asbestos ware, slate points, and flat-flaked points (Gjessing 1930). It may be added that copper arrowheads occur on the Kola peninsula in the late Neolithic and early metal ages (Gurina 1987;43).

There are two early north Swedish occurrences of copper. One occurrence is dated by context. It was a small piece of sheet metal and a badly corroded cylindrical bead of doubled and then rolled up sheeting (fig. $2: 4$ ), which were both found in a small excavation of a group of rectangular pit dwel- lings with accompanying graves at Lillberget in Överkalix parish, Norrbotten in 1990. The other finds consisted largely of typical Comb Ware in style II: 1 and of flint of eastern origin. The site lay by a beach deposit. The finds, the level of the beach, and the calibrated $14 \mathrm{C}$ dates, all show that the site was inhabited in ca. 3900 B.C. A small piece of copper-bearing sandstone $(0.6 \%)$ and artifacts interpreted as a stone anvil and parts of a crucible, are claimed to show that copper was smelted and processed at the site. The copper-bearing sandstone is explained as probably derived from the Volga-Ural region (Halén 1994:160). The present author finds it hard to understand why a raw material like this should be transported so far when there was the alternative possibility of acquiring smelted copper or finished artifacts. Is what was found at Lillberget really copper-bearing sandstone? The question deserves further investigation. However the arguments in the following pages will be based entirely on Ove Halén's publication.

In the other case from Norrland, an axelike object of copper from Vilhelmina parish in the interior of Västerbotten (fig. 3), the find circumstances are less informative. It was found by the author in a recent arrangement of stones at a deserted weekend hut on Lake Varris. The stones were mostly worked pieces of quartzite exactly like those found at the many prehistoric sites around the lake. The copper object and the pieces of quartzite must all have been brought from one or more of these sites. Someone had examined the object more closely by scraping it with a metal point.

Varris and the adjacent lakes, Stensjön, Insjön, Maksjön and Malgomaj were made in the late 50 's into a hydraulic reserve for hydro-electrical production. In anticipation of this the Riksantikvarieämbetet carried out a survey and what were for the time extensive excavations in the affected area. Later, water level fluctuations resulted in shore erosion. Archaeological material on an 
unexpectedly large scale, and partly with a new content, began to be exposed and progressively destroyed. To record what was happening, and to obtain further information Västerbotten Museum set up a several years' project under the direction of the author, the purpose of which was recording and excavation. The project was called "Archaeological Investigations into Artificially Regulated Lakes and Rivers in Västerbotten's Län", (Huggert 1979). Similar results were met in some other regulated areas - e.g. in Suomussalmi in Finland (Huurre 1982).

Of the recorded and sometimes excavated sites around Varris Lake, one is of particular interest for the above copper find. It was a shore settlement close to the hut where the object was found (no. 657 in Riksantikvarieämbetet's water regulation list, and Vilhelmina parish no. 234 in the National Register). This site was first found and was excavated by the Riksantikvarieämbetet be-

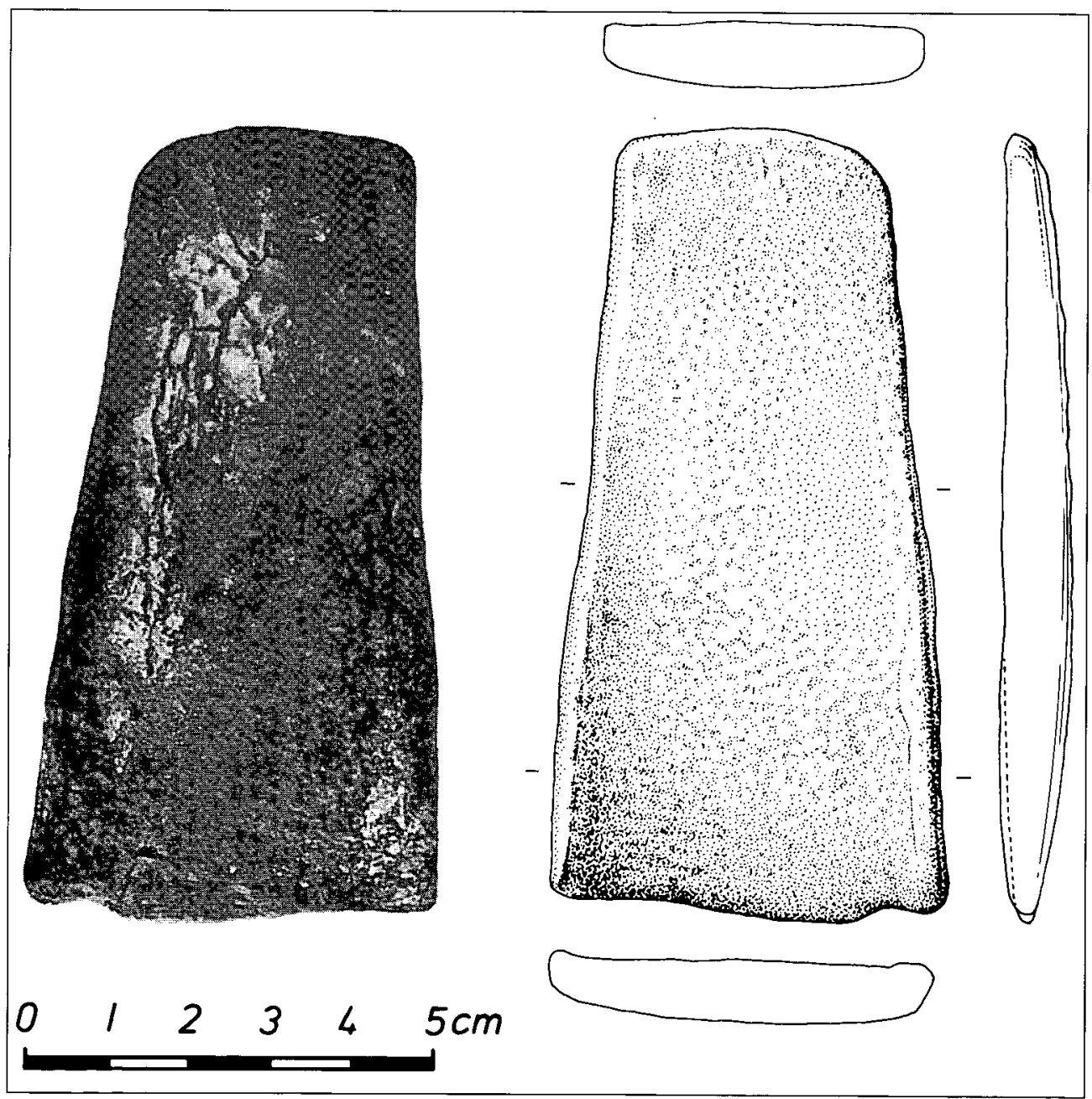

Fig. 3. The rough casting for an adze from Varris. Photo S. Wengelin, Västerbottens museum. Drawing Anders Eide, Stockholm. 
fore waterlevel regulation (Hvarfner 1959). The remains were quite considerable and derived from repeated settlements. Once when the author was examining eroded talus, he found a small piece of asbestos ware with remains of melted copper or bronze attached. An obvious possibility is therefore that the axe-like copper object and the pieces of quartzite were collected by an interested visitor from the already excavated site. As the excavation trenches had been left open, high water washed material out of their collapsing sides, while at times of low water finds lay exposed on the dry land surface.

Not far away two other sites were excavated by Riksantikvarieämbetet before water level regulation, yielding a material that includes moulds of soapstone, and in one case a bronze dagger (Oldeberg 1974, nos. 2944-2945). The dagger and a mould for a dagger blade are types that cannot be closely dated. Two moulds for socketed axes are regarded by Egil Bakka as variant local forms, "which cannot be classed as Ananino socketed axes, but are not nordic ones either" (1976:14,15).

The adze-like copper object (fig. 3) can be described as follows. Rough casting of rectangular adze with flat section, thinning towards blade and butt. One face is smooth and even, and towards the cutting edge distinctly concave. The other side is somewhat convex and has distinctly coarser surface structure. The whole object is much rounded in shape. The surfaces are uniformly and strongly corroded. The casting is $9.8 \mathrm{~cm}$ long, $5.1 \mathrm{~cm}$ wide, and $0.9 \mathrm{~cm}$ thick. Weight 238.9 g. As already said its sides had been scraped in recent times.

To judge from the object's appearance it was cast in an open mould. The mould cavity shaped the side with concave blade, so the other side must have solidified in the air. The adze needed to be finished by grinding and perhaps hammering.

There are no direct parallels in the rest of the north Swedish material. When completed the adze would probably have resembled the four-sided flat adzes of black slate with hollow blade (fig. 4), which occur during at least the later part of the Neolithic. The only parallel in metal to the Varris adze so far known from northern Fennoscandia is the one from Kukkosaari in eastern Karelia (fig. 2:2). However the two differ considerably in the way they were made.

\section{METAL COMPOSITION AND METHOD OF MANUFACTURE}

At first the adze roughout from Varris was thought to be of bronze. When Boliden Metal Company's central laboratory in Skelleftehamn was consulted, they very kindly offered an analysis free of charge. Their examination showed that the object was made of very pure copper, with the other elements only making up $0.6 \%$ of the total composition, viz. $0.005 \%$ silver, $<0.001 \%$ iron, $<0.001 \%$ nickel, $<0.001 \%$ zinc, $0.09 \%$ lead, $0.002 \%$ bismuth, $0.003 \%$ antimony, $0.48 \%$ arsenic, $<0.01 \%$ phosphorous, $<0.001 \%$ tin, $<0.01 \%$ aluminium, $<0.001 \%$ manganese, $<0.005 \%$ silica, $<0,001 \%$ magnesium, and $<0.001 \%$ terium (emission spectrography analysis from Boliden Mineral AB, Centrallaboratoriet, Skelleftehamn, Lab. no. 782826 , to whom we wish to offer our best thanks). Among the elements other than copper, arsenic $(0.5 \%)$ and lead $(0.1 \%)$ were the most important. The content especially arsenic is relatively high.

The fact that the casting is of such pure copper supports the hypothesis that it was cast in an open mould. The reason is that pure melted copper takes up much too much atmospheric gas, which is liberated again on casting. In an open mould the gases can easily escape instead of forming bubbles in the casting. If on the other hand copper is alloyed with other metals it cannot absorb so much gas. In this case it can readily be cast in closed moulds (Oldeberg 1976:76). The moulds from Suomussalmi include some 
two-piece moulds of very simple type suitable for making flat axes or adzes with rectangular, hexagonal, or pointed oval section. One of these actually came from Kukkosaari (fig. 5). The moulds were made of soapstone or similar material, and are thought to have been made locally (Huurre 1982:23f.).

The copper of the adze from Kukkosaari is purer than that of the Varris casting. The other elements only make up $0.3 \%$ of the total: $0.05-0.07 \%$ silver, $0.005 \%$ iron, $0.012 \%$ nickel, $<0.01 \%$ zinc, $0.009 \%$ lead, $<0.001 \%$ bismuth, $<0.01 \%$ antimony, $<0.07 \%$ arsenic, $<0.2 \%$ phosphorous, $<0.003 \%$ tin, $<0.002 \%$ aluminium, $0.003 \%$ manganese, $0.005 \%$ silica, and $<0.003 \%$ magnesium. It has been characterized as being of pure copper with natural impurities (Huurre 1982:20). We may observe the similarity of composition to that of the adze from Varris. Attention may be called to the slightly raised level of silver $(0.05$ $0.07 \%$ ) in the Kukkosaari object, while the elements with slightly raised values at Varris were arsenic and lead.

The ring from Suovaara was found on analysis to be of copper, but with a lower degree of purity. In addition to copper there was $0.055 \%$ cobalt, $0.055 \%$ zinc, $2.80 \%$ arsenic, $0.35 \%$ silver, $1.10 \%$ tungsten, and $0.00018 \%$ gold. The metal is thought to be made from oxide from the weathered surface of sulphide ore (Taavitsainen 1982:47). Attention may be called to the relatively large amounts of arsenic, tungsten, and silver.

The bead from Lillberget contained $97.91 \%$ copper. The other elements were $1.17 \%$ arsenic, $0.65 \%$ antimony, $0.12 \%$ lead, $0.08 \%$ silver, $0.03855 \%$ bismuth, $0.03429 \%$ nickel, $0.00036 \%$ iron, $0.00014 \%$ silica, $0.00001 \%$ aluminium, and magnesium in trace quantities (Halén 1994:154f.) The quantities in particular of arsenic $(1.2 \%)$, antimony $(0.7 \%)$, but also of lead $(0.1 \%)$ and silver $(0.1 \%)$, are quite distinct.

No analyses are published of the dagger from Karlebotn.

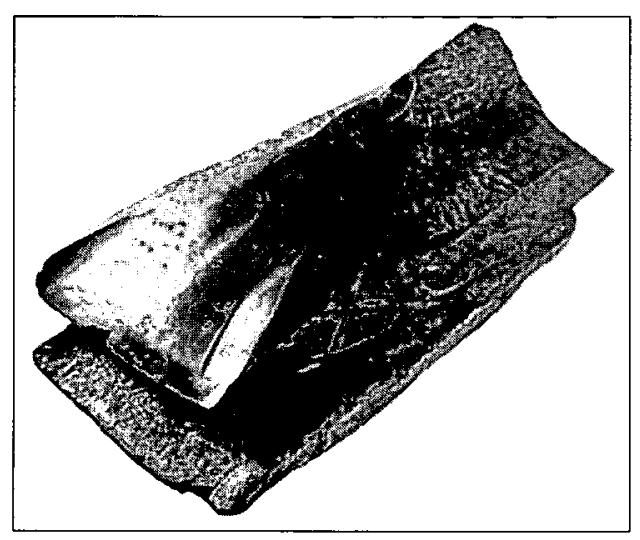

Fig. 4. The adze casting from Varris compared with a slate adze from Aliden in Degerfors parish, Västerbotten. Photo S. Wengelin.

From the above it emerges that the bead from Lillberget was the oldest of the analysed objects from north Fennoscandia dealt with here. Probably the ring from Suovaari is the next oldest, and the adze casting from Varris the youngest. It can be seen that the two oldest objects have a somewhat lower copper content than the two younger ones, whose level of copper is over $99 \%$. It may also be observed that the number of elements (impurities) is smaller in the older than the younger objects. Furthermore the individual impurity values are higher in the older material $(\max .2 .8 \%$ ) than in the younger $(<=0.5 \%)$. The highest content is that of arsenic. However there is no appreciable arsenic in the adze from Kukkosaari.

There seems thus to be a pattern in the material dealt with from Upper Norrland and eastern Finland. The material, however, is so small that it hardly justifies definite conclusions, but there is still scope for a hypothesis: the earliest copper objects had a composition like the raw material of which they were made. If they were shaped only by the mechanical working of natural native copper, the agreement would naturally be complete. When casting was introduced and 
became widespread older scrap objects became increasingly present in new metal. This applied particularly in areas peripheral to the primary raw materials. When copper from different sources and with different elemental composition was melted together, the resulting metal would contain the total elements of both, which would be averaged out in proportion to the amounts of the different metals present in the end-product. At the same time it can be supposed that metallurgical knowledge was sufficient to enable the processes to be manipulated to give a very pure copper ( $>99 \%$ ), meaning that the proportion of the other elements, the impurities, had been reduced. This made it possible to produce something else than random alloys. Birgitta Hulthén has had analysed two metal droplets from a crucible found at the site of Rå-inget I, facing Nämforsen on the Angermanälven river. According to Hulthén the results show that one droplet was copper and the other bronze "indicating that bronze alloy was produced locally and not just remelted" (1991:25). The published table shows however that there was tin in both droplets, so both seem to be bronze, though of somewhat different compositions.

When the adze casting from Varris was poured it was for technological reasons an advantage that the metal should contain arsenic. The melted metal would then run more easily into the hollow of the mould, and moreover the mechanical properties of the object were improved. On the other hand the poisonous arsenical gases liberated in melting were directly dangerous to health (Oldeberg 1942:149, 1943:135, 1976: 61). Bearing in mind that a small quantity of lead was also present in the casting, we may mention that also lead makes liquid metal flow more easily. Increasing amounts of lead increased the softness and flexibility of the casting (Oldeberg 1976:64), which after a time would make it impossible to produce an implement with a sharp cutting edge that would last.

\section{THE DEVELOPMENT OF METAL}

\section{TECHNOLOGY IN RUSSIA}

To understand what happened in cultural historical terms we need to know whether an alloy is a chance product or has been made deliberately. When the Russian specialist in prehistoric metallurgy, E.N. Chernykh, deals with Early and Middle Bronze Age metallurgy in the "Circumpontic Province", which extended from the Adriatic Sea in the west to the southern Urals and Volga in the east and from the upper Volga in the north to the Egean and Anatolia in the south, he uses the terms, metallurgically "pure" copper and arsenical bronze. The first of these "is characterized by the absence of any obvious signs of artificially introduced alloying components", while the other includes alloys "with arsenic concentrations ranging from a few tenths of 1 per cent to $10-15$ per cent and, in some anomalous cases, even up to 25-30 percent". By comparing the arsenic content of an analysed object with its method of manufacture and intended function it was, according to Chernykh, often possible to ascertain whether the object really belonged to the group of arsenical bronzes. More detailed studies have also been carried out with a more exact classification of the alloys (1992:145). Chernykh's procedures and comments show that when determining the character of an ancient alloy it is necessary to see modern metallurgical results from the standpoint of what was possible when the alloy was made. Conversely the analytical results give a better understanding of what prehistoric people were able to achieve.

Chernykh's researches also cover the beginnings of metal technology in the huge forest area between the Urals and Karelia, bordering on the northern periphery of the "Circumpontic Province". During the Early and Middle Bronze Age of the more southerly area (in Russian terminology from the 
end of the fourth until the beginning of the second millennium B.C. in calibrated radiocarbon terms), the smelting and the working of copper took place also among some of the hunting peoples of this area, whose material remains in other respects were of an exclusively Neolithic character.

In the middle of the area, around the upper and middle Volga and the rivers Oka and Klyazma are found remains from what is called the Volosovo culture. Excavations of its settlements have produced tubular beads, flat axes, awls, and other simple copper implements. Even crucibles with remains of melted metal have been found. These were obviously produced amid the daily activities of normal settlements. All the objects were made of chemically extremely pure copper, fully comparable with the metal in the copper-bearing sandstone found in hundreds of outcrops in the VolgaKama region and the western Urals. Chernykh's opinion is that the metalworking of the Volosovo culture was the result of external influences. The same is true of the Garin-Bor culture of the Kama/Vyatka area, close west of the Urals. The copper artifacts from its sites recall those of the Volosovo culture. However there are also daggers with pointed tang and objects such as doublespiral pendants. There are traces of local metalworking. The chemical composition of the metal is identical with that of the copper in the local sandstone.

Also in the western taiga on the NW side of Lake Onega in Russian Karelia copper was mined and worked in early times. The raw material was native copper from the bedrock. In the excavation of nearby settlements of the Comb-Pitted ware (typically Comb Ware) cultures have been found unworked pieces of natural copper, furnaces, crucibles, and hundreds of objects like awls, axes, rings, and tubular beads. The pieces of copper are strongly oxidized and would have had to be smelted to be any use for implements. Chernykh was strongly of the opinion that metal production and working evolved spontaneously in this region without being influenced from more southerly areas (1992:185ff). The Russian scholar A.P. Zhuravlev however regarded the development as having taken place under influences from the Ural area. He estimated also that ore exploitation began around 3000 B.C. (see e.g. Huurre 1986:53) - on a calibrated chronology about 3800 B.C. The time of typical Comb Ware according to recent Finnish research and calibrated radiocarbon can be placed at around 4000-3500 B.C.

Research in the Onega region has showed that artifacts and lumps of copper were much less common in the ensuing period, which was characterized by Asbestos Ware (Pöljä

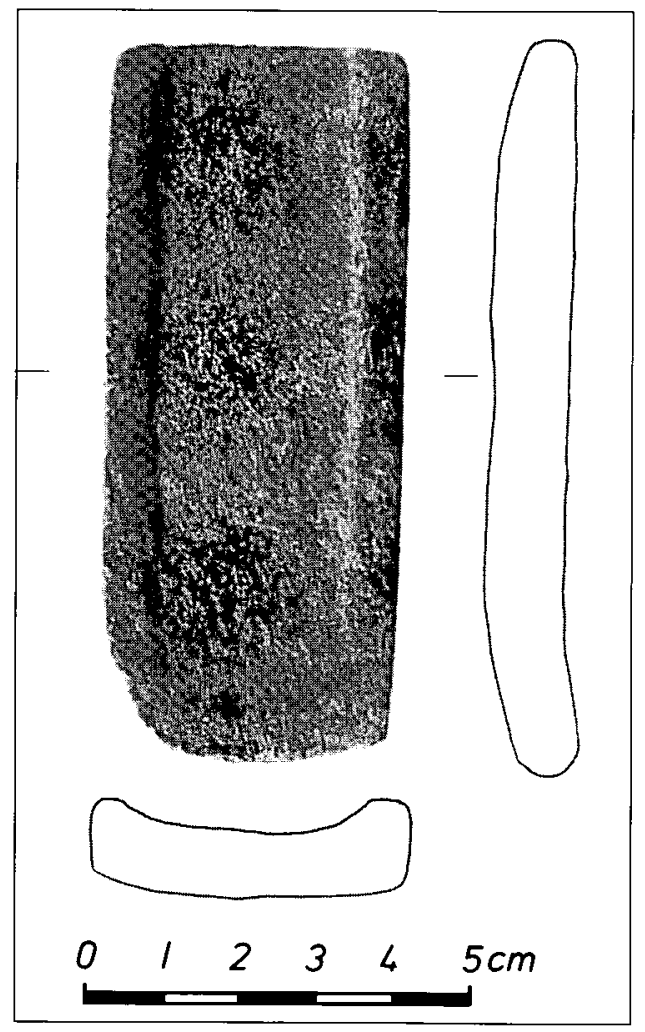

Fig. 5. Half of mould from Kukkosaari. Photograph and drawing from Museiverket, Helsinki. 
type). The local copper sources were clearly being used to some extent even into the Iron Age. However from the middle of the second millennium onwards more technologically advanced metalworking was being practised in Karelia. In Chernykh's opinion the older tradition had relatively little importance. The new development depended on external influences (1992:189).

\section{COMPARISON OF THE NORTH FENNOSCANDIAN WITH RUSSIAN MATERIAL}

The use of copper in northern Fennoscandia originated in the developments in metal technology taking place among the hunting peoples of the forest zone of Russia. The connection cannot be worked out in detail, as the artifacts are of very simple types. Ove Halén observed that tubular beads, like the one from Lillberget, are common all over the world (1994:159). J.-P. Taavitsainen finds parallels to the ring from Suovaara both in the Kama area and in Lithuania and Russian Karelia (1982:43). In the publication of the adze from Kukkosaari, Matti Huurre mentions similar objects found in Russia (1982:20). The dagger from Karlebotn has an oval hole near the end of the tang. This led Kjersti Schanche to call attention to a type of bronze dagger with large, pointed oval hole in the tang, which occurs in northern Italy, central Europe, and even in northern Poland (1989:63). However these daggers are some half millennium younger than the context in Karlebotn (Gimbutas 1965:419ff.). As already mentioned, copper daggers occur in the Volosovo culture. In the Middle Bronze Age daggers with hole in the tang occur in the "Circumpontic Province" (e.g. Chernykh 1992:152), where their dating agrees with that of the Karlebotn find. Nevertheless in a later paper Schanche did not find it necessary to point to more than the dagger's resemblance to slate daggers, which "suggests that it acquired its final form in the area where it was found, or in some other area with slate technology" (1994:193). The adze casting from Varris is unique and cannot be paralleled directly with finished objects. In any case axes and adzes with flat rectangular section are a very common form in both the Copper and Bronze Age. They are thought mostly to have been cast in bivalve moulds. The use of open single moulds should not necessarily be regarded as an indication of deficient knowledge of casting, as is clearly shown by a bronze founder's grave from Lebedi in the NW Caucasus. The grave is from the Maikop culture and dates from the Early Bronze Age. The grave goods included an open mould and two bivalve moulds for shafthole axes (see e.g. Chernykh 1992:80ff).

The artifacts found in northern Fennoscandia fit into the general picture of production found in the Russian forest area and further south. The question is therefore whether it is possible from the metal analyses to propose the origin of the copper itself. As already touched on, this requires that the analysed objects are not of mixed metal from different origins. This may be obvious in theory, but in practice it is really a matter of personal judgement. It is also necessary that there should be enough comparative data about raw materials. This last condition will probably never be met, as a single ore body can have very variable composition, as Chernykh points out. It is no advantage if the copper in the ore is very pure. Chernykh says that this makes it impossible to point out individual sources in the great Volga-Kama and west Ural area, or to distinguish reliably these coppers from the metal extracted from the copper-bearing sandstones of the Donets basin in the eastern Ukraine. There is yet another set of problems to overcome when attempting to find the source of the metal. The ingredients of the ore react differently to pyrotechnical processes. By comparing the composition of copper ores, slags, and smelted copper from various prehistoric contexts, Chernykh has 
established that the concentrations of gold and silver increase by a factor of between 10 and 100, as do arsenic, antimony and bismuth, while tin, lead and nickel are neutral or behave inconsistently. The metals of the iron group, such as iron, manganese, titanium, vanadium, cobalt, chromium and molybdenum, are concentrated in the slag and therefore diminished in the smelted copper. Cadmium and zinc disappear almost entirely in smelting. This should be more than enough to convince the reader that the linking of metal to ore is a complex question. Nevertheless Chernykh is of the opinion that the large research project of which he is the leader is fairly well able to connect a metal and the region where it was originally smelted. It is naturally simpler to determine the origin of a piece of ore (1992: 18ff).

We may now return to the north Fennoscandian material. As mentioned above, a small piece of copper-bearing sandstone was found in the excavation of a Comb Ware settlement at Lillberget in Norrbotten, and the excavator, Ove Halén believes it to be ore, probably brought from the Volga-Ural region. As the origin of the piece of sandstone is not obvious, the claimed provenance must have been deduced from what is known of the dominant stream of culture in northern Fennoscandia at the time. Halén mentions Alpine sources as another possibility (1994: 159f). He could also have mentioned the copper-bearing sandstones in the Donets basin in the Ukraine. When dealing afterwards with the cylindrical bead from Lillberg, which one could expect to have been made of copper smelted locally from the imported sandstone, it is no surprise that he finds agreements with the analyses of metal objects found in the Volga-Ural area. Now however he points out that it is not possible completely to exclude the Onega area (1994; 156). It seems thus that the analysis really gives no direct indication of provenance. This is only to be expected, bearing in mind the remarks of Chernykh's mentioned above about how difficult it is to provenance very pure copper, such as the metal smelted from the sandstone in the Volga-Kama and western Ural regions, or from the Donets basin in the Ukraine.

The Ural connection is also preferred for the metal of the ring from Suovaara (Taavitsainen 1982:45), while the metal of the adze from Kukkosaari is attributed in more general terms to the east, while the Onega region is considered as excluded (Huurre 1986:53). As intimated earlier, the author's opinion is that mixed material of different origin can be present in the adze, and the same applies to the adze casting from Varris.

It does not therefore seem possible to locate the copper objects found in northern Fennoscandia - or rather their copper - from the metal analyses. The object types are also somewhat insensitive. Opinions seem to be based essentially on where and in what context the objects were found, and on generally accepted opinions about what long-term connections and influences affected the population of the area at the time.

\section{FOREIGN CONNECTIONS - ESPECIALLY RUSSIAN FLINT}

The north Fennoscandian copper finds all occurred in Comb Ware or Asbestos Ware contexts. As well as the site at Lillberget with typical Comb Ware style II;I, Riksantikvarieämbetet's surveys in Norrbotten have in recent years found another with pottery in style II:2, and another again with early Comb Ware I:1. The sites lay on the contemporary coast (Halén 1994:147ff). This showed immediately that Comb Ware was in use also on the north to west sides of the Bothnian Gulf, which makes clearer the connections with the great Comb Ware region to the east found in some other structural features and artifacts. A very obvious case is flint of Russian origin, which occurs both as raw material, and as roughouts and finished products. The material from Lill- 
berget was largely flint, and both Carboniferous and Cretaceous flint was present at the site. The Carboniferous flint in all events must be of Russian origin (Halén 1994: 105ff). Implements of this kind of flint in Upper Norrland have already been the subject of a brief introductory study (Huggert 1984). It was found that finds were almost entirely restricted to the contemporary coastal tract, and occurred sporadically along the whole coast as far as the mouth of the Umea river in the south. An exception was an unfinished point found probably in Jämtland. Since then new material has been recorded or excavated as at Lillberget. There are also finds from sites in the middle Norrland coastal tract and in Hälsingland. This preliminary study was enough to show that Carboniferous flint was imported into Upper Norrland in Middle Neolithic or Comb Ware times, and also in the Late Neolithic and in the Epineolithic/Bronze Age.

When examining the raw material it was valuable for the author to be able to make direct comparisons with a large collection of flint from Gustaf Hallström's work on settlements on the shores of the Dvina Gulf of the White Sea. This collection reached Statens Historiska Museum in Stockholm in 1915 (inv. no. 15313). As the Norrland material being studied consisted entirely of points, it was interesting to be able to compare directly with points from the White Sea. The next step was to investigate the use of flint in Finland, especially its northern part, especially with reference to points. In 1975 more information on certain published material was obtained from Finnish archaeologists. In 1979 two of the points from Upper Norrland were sent to Helsinki for archaeological and petrological study. Unfortunately they had to be recalled in 1981 before any report had been received. Not until publication in 1985 (Kinnunen et al.) did the author realize that a wide and detailed study was begun in 1978 into the origin of the flint used in Finland in prehistoric times.
It is quite sure that flint from Carboniferous deposits east and south-east of the White Sea was brought via Finland to the coastal tract of Upper Norrland. Flint of the same kind reached northern Norway via the Kola peninsula (Huggert 1984). Settlement excavations have shown that on the Kola peninsula relatively more White Sea flint was used in the early metal age than there was earlier (Gurina 1987:43). The east-west connections through northern Finland in the Stone and Bronze Ages, especially through the Kainuu area, have been dealt with in a praiseworthy manner by Matti Huurre on the basis of topography, archaeological finds, and to some extent settlement remains (1985, 1986). Kainuu corresponds in a general way to the upper part of the Ulealven river basin. It has the source of its drainage at the watershed dividing it from rivers which finally enter the White Sea. At certain places anyone following one system upstream could easily cross the watershed and follow the other downstream. At several places there are easy ways from one drainage system over to the other. Another possibility on the north Finnish side was to cross between drainage basins and proceed in a north to south direction. Another route joined Kainuu with the Ladoga area to the SSE. In Huurre's opinion Carboniferous flint reached northern Finland by means of the east-west link. The same should apply to imports of copper, like the adze from Kukkosaari, and to the knowledge of casting indicated by the moulds from Suomussalmi. It may be pointed out that the ring from Polvijärvi is likeliest to be connected with the route between Lake Ladoga and Kainuu. Carboniferous flint may also have been transported this way. The Carboniferous beds lie in a long strip from the White Sea southwards, passing the SE part of Lake Onega (Atlas, map 9).

The geographical conditions for the establishment of deliberate connections and networks of this kind were basic to the life 
and evolution of the hunting communities of the vast forest area. There were good possibilities for contact favouring interchange of materials, skills, and ideas within cultural groups and between them. Material could in this way be disseminated more or less systematically over long distances. It is hardly likely that copper or Carboniferous flint were transferred directly by long-distance trade from their sources in the east to recipients in, for example, the coastal tract of the northern Bothnian Gulf, a view also held by Kjersti Schanche's in her paper on settlements and social structure in the Varanger area at around 2000 B.C. (1994:194f.).

In conclusion it may be pointed out that the use of copper reached northern Fennoscandia remarkably early. It was not merely a matter of importing finished objects from the east and south-east, for it has been discovered that metallurgy, including the melting of metal, was being practised very early at the northern end of the Gulf of Bothnia. The copper artifacts from northern Fennoscandia were of varied character, and this suggests that our knowledge of the earliest use of metal is still at a fairly rudimentary level.

Manuscript completed in 1994. Translated by David Liversage.

\section{REFERENCES}

Atlas géologique du Monde. Paris 1980. C.G.M.W. Unesco, Paris.

Bakka, E. 1976. Arktisk og nordisk i bronsealderen i Nordskandinavia. Det Kgl.Videnskabers Selskab. Museet. Miscellanea. 25. Trondheim.

Chernykh, E. N. 1992. Ancient Metallurgy in the USSR. The Early Metal Age. New Studies in Archaeology. Cambridge University Press.

Gimbutas, M. 1965. Bronze Age Cultures in Central and Eastem Europe. The Hague.

Gjessing, G. 1930. Et hustuftfunn fra Lebesby. Universitetets Oldsaksamling. Årbok. 3. pp. 111-128. Oslo.

- 1935. Fra steinalder til jernalder i Fimmark. Emologiske problemer. Institutt for Sammenlignende Kulturforskning. C. 3:3. Oslo.

- 1942. Yngre steinalder i Nord-Norge. Institutt for Sammenlignende Kulturforskning. B. 39. Oslo.

Gurina, N. N. 1987. Main Stages in the Cultural Development of the Ancient Population of the Kola Peninsula. Fennoscandia archaeologica. 4. pp. 35-48. Helsinki.

Halén, O. 1994. Sedentariness During the Stone Age of Northern Sweden in the Light of the Altrïsket site, c. 5000 B.C., and the Comb Ware site Lillberget, c. 3900 B.C. Source Critical Problems of Representativity in Archaeology: Acta arch. lundensia. Ser. prima in $4^{\circ} .20$.
Huggert, A. 1979. Visar fornminnesinventeringen den verkliga mängden fornlämningar? Västerbotten. 1979. pp. 68-72. Umeå.

- 1984. Flint also Came from the East A Contribution to the Knowledge of Upper Norrland's Prehistory. Archaeology and Environment. 2. pp. 57-74. Umeå.

- 1992. Vikarefångst vid Rickleåns mynningsvik för 4500 år sedan? Ett bidrag till vår kunskap om stridsyxekultur i övre Norrland. Arkeologi i norr. 3. pp. 83-104. Umeå.

- 1993. Fynden från stridsyxekulturens boplats vid Kallbäcken i Västerbotten. Arkeologi i norr: 4/5. pp. 155-157. Umeai.

Hulthén, B. 1991. On Ceramic Ware in Northem Scandinavia During the Neolithic, Bronze Age and Early Iron Age. A Ceramic - Ecological Study. Archaeology and Environment. 8. Umeå.

Huurre, M. 1982. Suomussalmen varhaista metallikautta. Suomen Museo. 88. pp. 11-30. Helsinki.

- 1985. Kainuu from the Stone Age to the Bronze Age. Finds and Cultural Connections. Fennougri et slavi 1983. Iskos. 4. pp. 42-50. Helsinki.

- 1986. The Eastern Contacts of Northern Fennoscandia in the Bronze Age. Fennoscandia archaeologica. 3. pp. 51-58. Helsinki. 
Hvarfner, H. 1959. Rapport över kulturhistoriska undersökningar vid Malgomaj inom Ångermanälvens kälområde, Vilhelmina socken. Lappland. 1957-58. 1-5. Riksantikvarieämbetet, Antikvarisk-topografiska arkivet, Stockholm.

Kinnunen, K., Tynni, R., Hokkanen, K. \& Taavitsainen, J.-P. 1985. Flint raw materials of prehistoric Finland: rock types, surface textures and microfossils. Espoo. Geological Survey of Finland, Bulletin. 334.

Kivikoski, E. 1964. Finlands förhistoria. Helsingfors.

Malmer, M. P. 1962. Jungneolithische Studien. Acta arch. lundensia. Ser. in $8^{\circ} .2$.

Meinander, C. F. 1954. Die Bronzezeit in Finnland. Finska fornminnesföreningens tidskrift. 54. Helsingfors.

- 1957. Kolsvidja. Studia neolithica in honorem
Aarne Äyräpääi. Finska fornminnesföreningens tidskrift 58. pp. 185-213. Helsingfors.

Oldeberg, A. 1942-43. Metallteknik under förhistorisk tid. 1-2. Lund.

- 1974-76. Die ältere Metallzeit in Schweden. 12. Stockholm. Kungl. Vitterhets Historie och Antikvitets Akademiens monografier. 53.

Schanche, K. 1986. Utgravning av en yngre steinalders hustoft i Karlebotn, Nesseby kommune, Finnmark. Tromura, kulturhistorie. 6. pp. 2332. Troms $\emptyset$.

- 1989. Nye funn fra yngre steinalder i Varanger. Viking. 52. pp. 53-71. Oslo.

- 1994. Gressbakkentuftene i Varanger. Boliger og sosial struktur rundt $2000 \mathrm{f} . \mathrm{Kr}$. Institutt for samfunnsvitenskap. Universitetet i Tromsø.

Taavitsainen, J.-P. 1982. A Copper Ring from Suovaara in Polvijärvi, Northern Karelia. Fennoscandia antiqua. 1. pp.41-49, Helsinki. 